\title{
Simulation and Demonstration Methods in Handover Implementation in Hospital
}

\author{
Indri Erwhani' ${ }^{1}$, Tri Kurniati², Abdul Aziz Alimul Hidayat ${ }^{3}$ \\ ${ }^{1}$ Master Degree Students in Nursing, University of Muhammadiyah, Jakarta \\ ${ }^{2}$ Department of Nursing, University of Muhammadiyah, Jakarta \\ ${ }^{2}$ Department of Nursing, University of Muhammadiyah Surabaya, 60113 Indoneaia \\ *Corresponding author: indri@stikmuhptk.ac.id
}

\begin{abstract}
Background: Problems occurring during implementation of handover is a common issue found in hospitals. One of the impacts of problems related to handover is patient safety and the quality of nursing care. Objectives: The Purpose of this paper is to explain the effectiveness of simulation and demonstration methods in training of effective SBAR communication on the implementation ofhandover in hospitals. Method: Pre-Experimental design within Pre-Post Test design was conducted at hospitals. Result: there is a difference in average value of handover implementation after and before training with simulation method, Conclusion: when applied in effective SBAR communication training in handover implementation, demonstration method is more effective than simulation method. Additionally, a training with those both methods will be more effective if accompanied by supervision and motivation.
\end{abstract}

Key words: Demonstration, Handover, SBAR, Simulation

\section{INTRODUCTION}

Implementation of handover is a routine activity that should be done as effectively as possible by the nurses in every change of shift-based service. The accuracy of the information transferred is essential so that the continuity of nursing care can proceed perfectly. Problems relating to the implementation of handover have become international concerns so that the standard of communication is saliently needed in order to improve the effectiveness of communication. Therefore, the information delivered in the handover time becomes effective and accurate and can improve patient safety as well as nursing service quality (Cohen \& Hilligos, 2009; Australian Health Care \& Hospital Association, 2009). In this regard, Communication method suggested by WHO is SBAR communication (Situation, Background, Assessment, Recommendation). This effective communication method, SBAR, should always be socialized and carefully explained to nurses. In order to carry effective and innovative socialization approaches, simulation and demonstration approaches are worthy of application (Sanjaya, 2012). Both of these methods can provide knowledge and information as well as changes in attitudes and behaviors (Sekar, 2012). Therefore, the purpose of this paper is to explain the effectiveness of simulation and demonstration methods in handover implementation in hospitals. 


\section{METHOD}

This research employed a quasi-experimental design within a pre-and post-test approach. The intervention group was divided into two groups, in which different interventions were done based on the planned protocol. This study was conducted at two hospitals, Islamic Hospital and Sultan Syarif Al Kadrie Hospital Pontianak. Before conducting the intervention, all groups were pre-measured to determine the ability or the initial value of the respondents prior to the intervention. After the intervention, a post test was given in both groups to determine the effects of the treatments. The outcomes or effects of the intervention were then compared with the initial intake value before the intervention given to the same group. Meaning, the results of pre-test and post-test, before the intervention and after intervention, were compared using the Wilcoxon Rank Test on the respondents. Samples of this study were 41 respondents (recruited from the two hospitals) consisting of team leaders and personals who are in charge of shift. While a nonparametric test, Mann Whitney Test, was used in order to know the effectiveness difference between the two effective communication training methods applied in the implementation of handover.

The instruments of measurement are questionnaires and observation sheets that are divided into 5 parts. The first part contains the respondent's characteristics; the second part consists of a set of 10 questions (Likert scale) related to policy regarding handover implementation. While the third part comprises 18 questions within the MCQ model aimed to assess the respondents' cognitive ability; the fourth part is another set of 18 questions (Likert scale) purposed to assess the changes of attitudes, and the fifth part is a set of 25 questions measured with Guttmann scale that is used for observation of the handover implementation.

\section{RESULT AND DISCUSSION}

Table 1 displays the characteristics of respondents. Of 22 respondents, 13 respondents $(59.1 \%$ ) have Diploma-III in nursing, and 51.9\% is female and $40.9 \%$ is male. The average age of the respondents was 27.7 with an average length of working of 5.18 years. While in RSI Yarsi Pontianak the table shows that of 19 respondents, 11 respondents $(57,9 \%)$ have diploma III in Nursing, and 13 respondents $(68,4 \%)$ are female and $31,6 \%$ of respondents are male. The average age of respondents was 26.74 with an average length of working of 5.16 years.

Table 1 Characteristics of Respondents at Yarsi and Sultan Syarif Al Kadrie Hospitals in Pontianak

\begin{tabular}{|c|c|c|c|c|c|c|c|c|}
\hline \multirow[t]{2}{*}{ Characteristics } & \multicolumn{4}{|c|}{ Sultan SY. Hospital } & \multicolumn{4}{|c|}{ Yarsi Hospital } \\
\hline & Mean & SD & $\mathrm{n}$ & $\%$ & Mean & SD & $\mathrm{n}$ & $\%$ \\
\hline$\overline{\text { Age }}$ & 27,7 & 4,1 & & & 26,7 & 4,1 & & \\
\hline Length of Work & 5,18 & 3,7 & & & 5,2 & 4 & & \\
\hline Education & & & & & & & & \\
\hline DIII in Nursing & & & 13 & 59,1 & & & 11 & 57,9 \\
\hline BA in Nursing & & & 9 & 40,9 & & & 8 & 42,1 \\
\hline Sex & & & & & & & & \\
\hline Male & & & 9 & 40,9 & & & 6 & 31,6 \\
\hline Female & & & 13 & 59,1 & & & 13 & 68,4 \\
\hline
\end{tabular}


Table 2 displays the comparison of different findings generated between the experimental group that employs simulation method and the experimental group that used demonstration method in the SBAR training in handover implementation. In the group treated with simulation method, the sub-variables of attitude and psychomotor have $p$ value $<0,05$. It statistically means that there is a difference in average scores of attitudes $(\mathrm{P}$ $=0,049)$ and psychomotor $(\mathrm{P}=0,032)$ between the outcomes of before and after the group was treated with the simulation method as the intervention. While for knowledge subvariable, the $\mathrm{p}$ value is $>0,05(0,093)$ which statistically means that there is no difference of knowledge score before and after the intervention. However, clinically there is a significant difference in the mean scores of pre and post-intervention, which increased from 77, 6 to 79.7. To illustrate it, there were 6 respondents out of 41 who experienced a decrease in score with an average decrease of 8.92. While in the implementation of handover using the simulation method 13 people experienced an increase with an average score of 10.50. Likewise, in the group that was treated with the demonstration method, all of the three sub-variables have a value of $\mathrm{P}<0.05$. This means that there is a statistical difference of average score before and after the intervention with the method of demonstration with the value of sub-variables vary by knowledge $(\mathrm{P}=0.005)$, attitude $(\mathrm{P}=$ $0,030)$ and psychomotor $(\mathrm{P}=0,002)$, as displayed in table 2 .

Table 2. The Score Comparison between Handover Implementation With Simulation and Demonstration Methods at Hospitals in Pontianak City, 2017

\begin{tabular}{|c|c|c|c|c|c|c|c|c|c|c|c|c|c|c|}
\hline \multirow{2}{*}{$\begin{array}{l}\text { Handover } \\
\text { Implementation }\end{array}$} & \multicolumn{7}{|c|}{$\begin{array}{l}\text { Simulation } \\
\text { Group }\end{array}$} & \multicolumn{7}{|c|}{$\begin{array}{l}\text { Demonstration } \\
\text { Group }\end{array}$} \\
\hline & $\begin{array}{l}\text { Pre } \\
\text { Mean }\end{array}$ & SD & $\begin{array}{l}\text { Post } \\
\text { Mean }\end{array}$ & SD & $\mathbf{N}$ & $\begin{array}{l}\text { Mean } \\
\text { Rank }\end{array}$ & $\mathbf{P}$ & $\begin{array}{l}\text { Pre } \\
\text { Mean }\end{array}$ & SD & $\begin{array}{l}\text { Post } \\
\text { Mean }\end{array}$ & SD & $\mathbf{n}$ & $\begin{array}{l}\text { Mean } \\
\text { Rank }\end{array}$ & $\mathbf{P}$ \\
\hline Knowledge & 77,6 & 4,5 & 79,7 & 4,5 & $\begin{array}{l}6 \\
13\end{array}$ & $\begin{array}{l}8,92 \\
10,5\end{array}$ & 0,093 & 73,7 & 7,2 & 78,5 & 3,5 & $\begin{array}{l}6 \\
13\end{array}$ & $\begin{array}{l}4,33 \\
12,62\end{array}$ & 0,005 \\
\hline Attitude & 87,5 & 10,4 & 93.1 & 9,6 & $\begin{array}{l}11 \\
11\end{array}$ & $\begin{array}{l}6, \\
17\end{array}$ & 0,049 & 85,6 & 11,2 & 90,9 & 10,1 & $\begin{array}{l}4 \\
9\end{array}$ & $\begin{array}{l}3,63 \\
8,5\end{array}$ & 0,030 \\
\hline Psychomotor 1 & 84,5 & 6,7 & 85,5 & 6,7 & $\begin{array}{l}0 \\
0\end{array}$ & $\begin{array}{l}0 \\
0\end{array}$ & 1,000 & 85,1 & 4,7 & 84,4 & 4,6 & $\begin{array}{l}2 \\
0\end{array}$ & $\begin{array}{l}1,5 \\
0\end{array}$ & 0,021 \\
\hline Psychomotor 2 & & & 88 & 7,6 & $\begin{array}{l}9 \\
12\end{array}$ & $\begin{array}{l}8,61 \\
12,79\end{array}$ & 0,185 & & & 85,6 & 3,6 & $\begin{array}{l}9 \\
9\end{array}$ & $\begin{array}{l}8,39 \\
10,61\end{array}$ & 0,180 \\
\hline Psychomotor 3 & & & 91,8 & 5,7 & $\begin{array}{l}5 \\
15 \\
\end{array}$ & $\begin{array}{l}5,3 \\
12,23\end{array}$ & 0,032 & & & 90,4 & 3,8 & $\begin{array}{l}2 \\
17 \\
\end{array}$ & $\begin{array}{l}9,5 \\
10,6\end{array}$ & 0,002 \\
\hline
\end{tabular}

Of the two methods based on the average-score difference, it can be concluded that there is a psychomotor change in the third observation. As generated by both statistical and clinical tests, the demonstration method is more effective than the simulation method is. The researchers' analysis regarding the two training methods applied is that the results of both methods show that behavioral changes occurred in the third psychomotor observation. Therefore, this finding is in line with Guthrie's theory of behavior as well as the Skinner's theory that suggests the appearance of behavioral changes resulted from reinforcement and stimulus. Furthermore, affirming the theory that strengthening and stimulus can be forms of SOP policy, supervision and motivation provided. Thus, this reinforcement can change the existing conditions (Hall \& Lindzey,1993 ; Notoatmojo, 2010).

The result of handover implementation which comprised the assessment of knowledge, attitude and psychomotor obtained $\mathrm{p}$ value> $0.005(0,112)$. This statistically means that there is no difference of average of handover implementation between simulation and demonstration training methods, with the average rank of 22,57 for 
simulation approach and 19,18 for Demonstration approach. Therefore, it can be concluded that the two methods are equally affecting the implementation of handover. Nevertheless, the method of demonstration more effectively affects the implementation of handover after compared with the simulation method. Thus, an alternative hypothesis is accepted that there is a difference in the effectiveness of simulation and demonstration methods in training of effective communication in the implementation of handover.

Accordingly, the researchers draw some analyses that the demonstration method demonstrates and shows the process and situation to the participants in which case the actual handover exists (Sanjaya, 2012). In addition, the demonstration method also provides a direct handover experience to the trainees. This is because the participants directly practice in the patient's bed for direct experience will be stronger and harder to forget. Immediate experience is capable to stimulate the brain and the five senses making it easier for participants to remember and perform the same process again (Niven, 2012 ; Fitria, 2013).

\section{CONCLUSION}

The results prove that both methods are equally effective. However, the demonstration method is more effective in affecting the implementation of the handover. Therefore, based on this result, the hospital management can consider the approach of this method to be applied to continuous training by enabling multilevel supervision and organizing the standard operating procedures in accordance with the standards used by researchers in this study.

\section{ACKNOWLEDGEMENT}

The researchers would like to thank the Director of RSU Sultan Syarif Alkadri and RSI Yarsi Pontianak, as well as their colleagues Hartono and Cau Kim Jiu who helped the data collection process used in this research.

\section{REFERENCES}

Australian Health Care \& Hospital Association. (2009). Clinical Handover; System Change, Leadership and Principal .http://www.ihffih.org/content/download/1350/13051/file/clinical\%20handover\%20system\%20ch ange\%20leadeship\%20and\%princple.pdf. Diakses februari 11 Februari 2017.,pp: $2-19$

Brown, R, Rasmussen, R, Baldwin, I, \& Wyeth, P, (2012), Design and implementation of a virtual world training simulation of ICU first handover processes, Australian Critical Care, 25(3), 178-187.

Cohen \& Hilligos. (2009). Handoffs in Hospital; A Review of Literature on Information Exchange While A Transferring Patient Responsibility Control.,pp: 1-49

Fitria, C.M. (2013). Efektifitas Pelatihan Komunikasi SBAR Dalam Meningkatkan Motivasi dan Psikomotor Perawat di Ruang Medikal Bedah RS PKU Muhammadiyah. Surakarta.

Manser, T, Foster, S, Flin, R \& Patey, R, (2012), Team communication during patient handover from the operating room, Human Factors: The Journal of the Human Factors and Ergonomics Society. 
Toccafondi, G, Albolino, S, Tartaglia, R, Guidi, S, Molisso, A, Venneri, F, Peris, A, Pieralli, F, Magnelli, E, Librenti, M, Morelli, M, \& Barach, P, (2012), The collaborative communication model for patient handover at the interface between high-acuity and low-acuity care, BMJ Quality \& Safety, 21(1).

Niven, N. (2012), Health Psychology An Introduction For Nurses and Other Health Care Profesionals (Translation). Jakarta: EGC, pp: 192 - 198 